\title{
Management as a Risk Factor for Farm Injuries
}

\section{J. Suutarinen}

\begin{abstract}
The organizational injury theory focusing on management issues could provide new viewpoints on causes and prevention of injuries in agriculture. The objective of this study was to test whether the quality of farm management is associated with farm injuries. A cohort of 134 farms was used to examine the relationship between farm injuries and selected management, farm, and farm operator characteristics. The number of machines and musculoskeletal disorders were found to be risk factors for injuries $(R R=2.34,95 \% C I$ 1.27-4.31, and $R R=1.75,95 \%$ CI 1.14-2.69). Management quality (significant work delays) was associated with injuries $(R R=1.59,95 \%$ CI 1.00-2.52) in univariable analysis but not in the multivariable model. Although the results for the association between injury and management quality were not conclusive, this line of research should be continued.
\end{abstract}

Keywords. Agriculture, Ergonomics, Farm machinery, Farm management, Injuries, Injury prevention, Safety.

A griculture is a challenging sector for efforts to promote occupational safety and health. Farming is commonly based on family entrepreneurship. Many characteristic hazards related to the workers, work environment, and work tasks have been identified, but a recent review of farm safety interventions (DeRoo and Rautiainen, 2000) concluded that there is little evidence that farm safety educational programs are effective. The effectiveness of education has also been questioned by Murphy (1981, 1986), Geller et al. (1990), and Reis and Elkind (1997). Influencing the attitudes of the farming population is laborious, and implementing safety regulations and enforcement is culturally unacceptable. Therefore, new approaches should be sought. The organizational injury theory has become a prevailing paradigm in safety science recently. The focus has been on management issues rather than on personal characteristics or behavior (Harvey, 1984; Laflamme, 1990; Reason, 1995). However, the organizational injury theory has been developed for organizations that involve complex technology and/or employ many workers. This study aims to determine whether the organizational injury theory applies to farming as well.

\section{Literature Review}

The literature on injury theories and related empirical findings were reviewed to form a hypothesis for this study. The hypothesis was tested with empirical data using a cross-sectional case-control design.

Article was submitted for review in April 2003; approved for publication by the Journal of Agricultural Safety and Health of ASAE in July 2003.

The author is Juha Suutarinen, Senior Research Scientist, MTT Agrifood Research Finland, Agricultural Engineering Research, Vakolantie 55 FIN-03400 Vihti, Finland; phone: +358-9-224251; fax: +358-9-2246210; e-mail: juha.suutarinen@mtt.fi. 


\section{Theories}

Researchers from various disciplines, such as medicine, sociology, psychology, engineering, management science, and education, have addressed the problem of injuries. Furthermore, injury research, or safety science, is becoming a discipline in its own right (Harvey, 1984; McClay, 1989; Laflamme, 1990; Adams, 1992). Injury theories supply a priori assumptions and hypotheses for causes of injuries, and investigation methods are used for post hoc analysis of injuries. Characteristically for a young science, there are many rival or complementary theories of injury causation. According to modern injury theories, the setting, conditions, and preconditions, which allow the existence and materialization of a hazard, should be comprehensively identified (Rasmussen, 1986; Groeneweg, 1992; Reason, 1995, 1997). Hazards have to be examined as factors of the production system. They are not isolated factors (Häkkinen, 1978). The underlying injury risk factors in production, including management, are hidden in so-called latent, general failures. These include factors concerning incompatible goals, housekeeping, procedures, and error-enforcing conditions (Reason, 1997). In terms of time and space, underlying factors are more distant from the injurious event than proximal injury factors, which take place just before the final event (Groeneweg, 1992; Reason, 1995, 1997).

In the economic and management disciplines, the word "management" has several meanings. Drucker (1999) argues that the definition of management (as a discipline and practice) has to be operational. It needs to focus on results and performance across the entire economic chain rather than base itself on legal or political assumptions. His suggestion is that management is the specific tool, the specific function, or the specific instrument to make the institution capable of producing results outside of itself. The focus of farm management is said to be on goal setting, communication, information processing and analysis, negotiation, and control (Jolly, 1983). The three broad management functions involve planning, implementing, and control (Benson, 1999). According to Parnell et al. (1999), the terms management science, systems engineering, and operations research refer to the same process, which is the application of systems analysis to gain a better understanding of the problem and make decisions that increase profit. Here, the term "management" is used in compliance with these definitions.

\section{Empirical Findings}

A considerable amount of research has been done on the epidemiology of farm-related injuries. By 1992, a bibliography of the epidemiology of farm-related injuries already included 343 journal reports and 180 monographs, mostly in English, published between 1914 and 1991 (Nordstrom et al., 1992). Since then, the accumulation of scholarly research reports has grown substantially. Various injury risks have been identified.

Agricultural machinery has been identified as a major hazard (e.g., Browning et al., 1998; Gerberich et al., 1998; ILO, 2000; McGwin et al., 2000; Rasmussen et al., 2000; Gerberich et al., 2001). The tractor has been identified as the primary machinery hazard (Lee et al., 1996; Thelin, 1998; Franklin et al., 2001). In Finland, the number of different types of machines used in farm production was found to be the most important determinant of injuries, regardless of factors such as farmer's age, work experience, size of farm, or vocational education (Tupi and Vohlonen, 1983).

Animals constitute another significant hazard source. Work with large animals and herds of animals involves high risk because of the unpredictable behavior of animals and their potential to cause severe trauma (Hansson et al., 1989; Boyle et al., 1997; 
Browning et al., 1998; McGwin et al., 2000; Rasmussen et al., 2000; Gerberich et al., 2001; Park et al., 2001).

Safe execution of tasks requires sufficient working ability in relation to the demands of the work. Limited work ability has been identified as a risk factor for injury (Brison and Pickett, 1991; Browning et al., 1998; Lewis et al., 1998; MacCrawford et al., 1998). Musculoskeletal disorders (MSD) are important causes of disability among farmers in Finland (Manninen, 1996; Perkiö-Mäkelä, 2000). In the medical assessments for granting disability pensions, $77 \%$ include at least one musculoskeletal diagnosis. Predictors of musculoskeletal disability include age, gender, overweight, and psychological distress (Manninen, 1996).

The evidence of the effectiveness of interventions is inconclusive. On one hand, a positive correlation between a safety index score and participation in a farm safety program has been detected (Schafer and Kotrlik, 1986). An injury reporting bias has been suggested as an explanation for the negative correlation between safety behavior and injury (Crawford et al., 1998). On the other hand, it has been suggested that safety attitudes and safety training do not affect the injury frequency (Murphy, 1981; Reis and Elkind, 1997; Lewis et al., 1998; Park et al., 2001). Vocational education, including relevant management issues and safety training, should result in safer management practices, but as discussed by Murphy (1981, 1986), Geller et al. (1990), Reis and Elkind (1997), and DeRoo and Rautiainen (2000), results have been contradictory. Consequently, improvement in the design of machines, environment, and systems has been proposed as being preferable to attempts to changing people's safety attitudes or behavior (Heidt and Groh, 1984). However, merely technical safety implementation without the motivation of workers does not improve safety (Aschenbrenner and Biehl, 1994). According to some theories, the most important step would be to reduce hazards at work by improving business management (Groeneweg, 1992; Salminen, 1997). In agriculture, unfortunately, farmers often lack professional management skills and time (Miller et al., 1998).

Farm work tasks are highly variable. The elevated injury risk in exceptional situations, such as correction of malfunction, seems to be common, irrespective of the industry (Saari and Lahtela, 1981; Salminen et al., 1991; Suutarinen, 1996). Some factors, such as weather, are difficult or impossible to control. The lack of direct control of such factors does not mean, however, that nothing can be done to master the influences of variation. Better work planning is needed to reduce the risk-taking that leads to injuries (Salminen, 1997). Ultimately, the farmer and his/her choices determine the functionality of the production system on the farm within the infrastructure of the society (Thu et al., 1997).

A farm is not a closed system; it is connected to the surrounding community. Therefore, in addition to the individual and organizational management factors discussed above, the sociological point of view is also relevant. Economic and other restrictions imposed by the national and international community and the appreciation received by the producers are also basic factors of occupational safety and health in the industry. However, these factors are outside the scope of this article.

The aim of this study is to examine whether there are latent, controllable, underlying injury risk factors in agriculture that are in accordance with the organizational injury theory. Based on the findings presented above, it is hypothesized that injuries are more probable among principal operators with inferior farm management practices. 


\section{Methods and Materials}

A study sample of 134 farms was collected to investigate the causes and underlying factors of tractor injuries (Suutarinen, 1992, 1997). The study cohorts consisted of 73 case farms (one or more injuries during 12 months preceding the survey) and 61 control farms (no injuries during 12 months preceding the survey). The case farms were primarily tractor injuries on dairy farms. The response rate among eligible case farms was $50 \%$. Sixty of the case farms were visited for in-depth investigation. The control farms were matched to case farms on type of production, farm size, and location. The response rate on eligible controls was $39 \%$.

Most principal operators were male (95.5\%). The responding and non-responding control farms did not differ in terms of arable land area. The study sample is compared with the agricultural census of 1990 and 2000 in table 1 . The sample is more similar to the 2000 census than to that of 1990, but the respondents were younger, more educated, and had larger farms. Milk production was more prevalent in the study sample. These differences, as well as the low response rates and the fact that the injuries were primarily tractor injuries rather than randomly selected injuries of any type, must be considered when interpreting the results.

\section{Variables}

The primary dependent variable was the incidence of farm injuries during the 12 months preceding the survey. This variable was dichotomized into two categories: no injuries (controls), and one or more injuries (cases). The respondents were asked to describe each injurious event in terms of type of injury, circumstances, cause, physician's care, hospitalization, and the duration of disability.

The independent variables included sociodemographic, medical, as well as production - and management-related factors. Specific variables included: delays in production, number of machines, musculoskeletal disorders, exhaustion, general

Table 1. Comparison of selected characteristics in the study sample with the 1990 and 2000 agricultural census in Finland.

\begin{tabular}{|c|c|c|c|c|c|}
\hline \multirow[b]{2}{*}{ Characteristic } & \multicolumn{2}{|c|}{ Census of Agriculture } & \multicolumn{3}{|c|}{ Study Sample $(n=134)$} \\
\hline & $1990^{[\mathrm{a}]}$ & $2000^{[b]}$ & Total & $\begin{array}{c}\text { Cases } \\
(n=73)\end{array}$ & $\begin{array}{l}\text { Control } \\
(n=61)\end{array}$ \\
\hline Mean age of operator (years) & 48.5 & 47.7 & 44.0 & 43.8 & 44.3 \\
\hline \multicolumn{6}{|c|}{ Vocational education in agriculture, percentage of operators $(\%)$} \\
\hline Working experience only & 82.5 & 64.9 & 60.2 & 62.5 & 57.4 \\
\hline Basic education & 16.2 & 29.4 & 35.3 & 34.7 & 36.1 \\
\hline Higher education & 1.3 & 5.7 & 4.5 & 2.8 & 6.6 \\
\hline Mean cultivated area (ha) & 17.3 & 27.8 & 28.5 & 27.9 & 28.9 \\
\hline \multicolumn{6}{|l|}{ Type of production (\%) } \\
\hline Milk production & 33.7 & 28.7 & 47.8 & 50.7 & 44.3 \\
\hline Pig or poultry husbandry & 7.4 & 7.0 & 11.9 & 6.8 & 18.0 \\
\hline Other domestic animal husbandry & 8.9 & 6.7 & 6.0 & 6.8 & 4.9 \\
\hline Crop production & 36.8 & 48.7 & 26.1 & 32.9 & 31.2 \\
\hline Other & 13.2 & 8.9 & 8.2 & 2.7 & 1.6 \\
\hline Mean number of tractors on farm & 1.7 & 2.2 & 2.2 & 2.2 & 2.2 \\
\hline
\end{tabular}

[a] Agricultural Census 1990 (1992a, 1992b); Maatalouslaskenta 2000 (2001).

[b] Yearbook of Farm Statistics (2001); Maatalouslaskenta 2000 (2001). 
health, age of principal operator, vocational education, type of production, and land area.

\section{Statistical Analysis}

The distribution of injuries in the sample was characterized to help select appropriate statistical methods. This distribution appears to be close to a Poisson distribution. Therefore, the appropriate statistical methods could include Poisson regression. When dichotomizing the incidence of injuries into zero and one or more injuries groups, chi-squared and logistic regression can be used. Poisson regression modeling (including multiple regression models to account for interrelationships between explanatory variables) was selected as the primary method in this study.

\section{Results}

\section{Empirical Findings}

The distribution of the study sample was compared to the distribution of compensated injuries in the population of all those insured by the Finnish Farmers' Insurance Institution during 2000 (table 2). The study design and the fact that only compensated injuries appear in the insurance institution data explain the differences in distributions. Forty-five percent of the principal operators reported no injuries during the preceding 12 months; the remaining 55\% reported one to five injuries. Table 3 presents the results of the multiple regression analysis, along with the corresponding unadjusted results.

The significant reported delays in operations were related to the higher injury incidence in the crude rate ratios. However, when adjusted with other variables, the effect did not remain statistically significant. The increasing number of on-farm machines was associated with increasing injury rates with both the crude and adjusted rates, except the category of 15-25 machines, when adjusted for eight other variables presented in table 3. Musculoskeletal disorders were shown to have a sizable effect even when adjusted for other variables. Exhaustion was related to the higher injury rate when unadjusted, but in the multiple regression models the effect failed to reach the predefined confidence interval. Having health complaints appeared to be associated with injuries, but the relation was not statistically significant. The age of the respondents ranged from 24 to 64 years. Since the farm contact information was

Table 2. The distribution of injuries in the study sample and among all insured farmers in Finland.

\begin{tabular}{cccc}
\hline Number of Injuries & Number of POs ${ }^{[\mathrm{a}]}$ & \% Study Sample & \% Insured Farmers ${ }^{[\mathrm{b}]}$ \\
\hline 0 (control) & 61 & 45.5 & 93.6 \\
1 & 39 & 29.1 & 5.7 \\
2 & 21 & 15.7 & 0.6 \\
3 & 6 & 4.5 & 0.1 \\
4 & 5 & 3.7 & $<0.1$ \\
5 & 2 & 1.5 & $<0.01$ \\
6 & 0 & 0 & $<0.01$ \\
7 & 0 & 0 & $<0.01$ \\
\hline Total & 134 & 100 & \\
\hline
\end{tabular}

[a] $\mathrm{PO}=$ principal operator.

[b] During 1 Jan. 2000 to 31 Dec. 2000 (Eskola, 2002). 
Table 3. Unadjusted and adjusted injury rates by farm and farmer variables in the study sample.

\begin{tabular}{|c|c|c|c|c|c|}
\hline \multirow[b]{2}{*}{ Variable } & \multirow[b]{2}{*}{ Category } & \multicolumn{2}{|c|}{ Unadjusted } & \multicolumn{2}{|c|}{ Adjusted $^{[\mathrm{b}]}$} \\
\hline & & $\mathrm{RR}^{[\mathrm{a}]}$ & 95\% C.I. & RR & $95 \%$ C.I. \\
\hline \multicolumn{6}{|l|}{ Delays } \\
\hline & Insignificant & 1.00 & & 1.00 & \\
\hline & Significant & 1.59 & $1.00-2.52$ & 1.22 & $0.73-2.07$ \\
\hline \multicolumn{6}{|c|}{ Number of on-farm machines } \\
\hline & $<15$ & 1.00 & & 1.00 & \\
\hline & $15-25$ & 1.62 & $1.00-2.63$ & 1.26 & $0.76-2.11$ \\
\hline & $>25$ & 2.81 & $1.59-4.98$ & 2.34 & $1.27-4.31$ \\
\hline \multicolumn{6}{|c|}{ Musculoskeletal disorders } \\
\hline & Not at all or seldom & 1.00 & & 1.00 & \\
\hline & Frequent or med. care & 1.88 & $1.27-2.77$ & 1.75 & $1.14-2.69$ \\
\hline \multicolumn{6}{|c|}{ Exhaustion } \\
\hline & No complaints & 1.00 & & 1.00 & \\
\hline & Exhaustion & 1.77 & $1.12-2.80$ & 1.58 & $0.95-2.64$ \\
\hline \multicolumn{6}{|l|}{ Health } \\
\hline & Good & 1.00 & & 1.00 & \\
\hline & Complaints & 1.70 & $0.91-3.14$ & 1.51 & $0.76-3.03$ \\
\hline \multicolumn{6}{|l|}{ Age } \\
\hline & $24-34$ & 1.00 & & 1.00 & \\
\hline & $35-54$ & 1.21 & $0.77-1.88$ & 1.19 & $0.71-2.00$ \\
\hline & $55-64$ & 0.78 & $0.39-1.55$ & 0.73 & $0.34-1.57$ \\
\hline \multicolumn{6}{|c|}{ Vocational education } \\
\hline & Agric. education & 1.00 & & 1.00 & \\
\hline & No agric. education & 1.06 & $0.74-1.52$ & 0.86 & $0.55-1.32$ \\
\hline \multicolumn{6}{|c|}{ Farm type } \\
\hline & No production animals & 1.00 & & 1.00 & \\
\hline & Animals involved & 1.01 & $0.70-1.46$ & 0.86 & $0.57-1.32$ \\
\hline \multicolumn{6}{|c|}{ Cultivated area (ha) } \\
\hline & $\leq 39$ & 1.00 & & 1.00 & \\
\hline & $\geq 40$ & 0.87 & $0.53-1.44$ & 0.74 & $0.43-1.27$ \\
\hline
\end{tabular}

[a] $\mathrm{RR}=$ injury rate (injuries/person per year) of this category / injury rate (injuries/person per year) of referent category.

[b] Adjusted by all variables in the model.

acquired from the database of the Farmers' Social Insurance Institution, the limited age scale originates from the Finnish statutory pension and injury insurance for agricultural entrepreneurs between the ages of 18 and 65. There was no clear influence of age or of vocational education. Neither the farm type nor the cultivated area had any influence on the injury rate.

\section{Discussion}

The aim of this study was to examine underlying injury risk factors in farming and especially to test the hypothesis that lower quality management is associated with injuries. This test would indicate whether the organizational injury theory is relevant to farm injuries. Several conventional factors were used to adjust for interrelationships between explanatory variables. 
The actual variable used to measure management (i.e., delays) showed that, in the unadjusted analysis, delays in operation were associated with a higher injury rate. However, when adjusted for other variables, the effect was not statistically significant, although the trend was as expected.

The connection between a growing injury rate and an increase in the number of machines used in farm operations was expected and consistent with previous research (Tupi and Vohlonen, 1983; Browning et al., 1998; Gerberich et al., 1998; ILO, 2000; McGwin et al., 2000; Rasmussen et al., 2000; Gerberich et al., 2001). Machines are an important source of injuries, especially for men in agriculture, and the exposure to machinery is expected to grow as more machinery becomes involved in production.

Reported health complaints showed an expected relationship with higher injury rates, although not statistically significant, but the effect of musculoskeletal disorders was clear. The relation between health and injuries is documented in the literature (Penttinen and Valonen, 1995; Browning et al., 1998; Crawford et al., 1998; Lewis et al., 1998; Park et al., 2001). Exhaustion was significantly related to the higher injury rate in the crude analysis, but not in the multivariable analysis. It is has been noted in earlier studies that when the working capacity, whether mental or physical, is not equal to the tasks to be performed, the injury probability increases (Browning et al., 1998; Lewis et al., 1998; MacCrawford et al., 1998; Zwerling et al., 1998).

Injury rates were not statistically different between the age groups. This result is not consistent with several previous studies, which have found elevated injury probabilities either for the young (Geller et al., 1990; Carstensen et al., 1995; Zhao et al., 1995; MacCrawford et al., 1998; Gerberich et al., 2001) or for the old (Erlich et al., 1993; Zhao et al., 1995; Gerberich et al., 1998; Pickett et al., 2001). The lack of very young and old operators in the study sample might be at least a partial explanation. However, in Finland, Virtanen et al. (2003), with their data of a national cohort of 69,629 farmers and 11,657 compensated injuries of full-time farmers, were not able to find a clear age effect, except for a peak among those in the 50-54 age category. Furthermore, in a prospective cohort study, Park et al. (2001) were also unable to find any consistent pattern with respect to age. Contradictory results may derive from both the differences in study design and the fact that age as such is not the explanatory factor for injuries but rather a proxy for many types of factors related, for instance, to impaired working capacity (e.g., deficient hearing or sight) (Browning et al., 1998; Zwerling et al., 1998). The lack of conformity with some other findings might also be explained by the fact that it was not possible to measure the exposure to hazards in terms of the working hours of principal operators in this study. Besides explaining factors related to age, the Finnish early retirement system may have an influence on the age effect, as discussed by Virtanen et al. (2003).

Vocational education was not shown to have a significant effect on injury risk. This is consistent with the findings of Murphy (1981), Reis and Elkind (1997), Lewis et al. (1998), Park et al. (1998), and DeRoo and Rautiainen (2000) on the limited success of education and safety training in promoting safety. However, information about the substance and quality of vocational education in respect to safety management and management in general was not available. For this reason, it is not possible to determine whether this result is due to the ineffectiveness of education, a lack of educational material on safety, or limitations of the cross-sectional study. Although it was not possible to determine why education did not influence the incidence of injuries, one should consider the possibility that the result may be explained by a lack of material or insufficient focus on management and safety issues in education.

A higher injury risk related to bovine tending has been detected elsewhere (e.g., Boyle et al., 1997; Rasmussen et al., 2000; Gerberich et al., 2001; Park et al., 
2001, Virtanen et al., 2003). In this study sample, $95.5 \%$ of principal operators were male, while in Finland, cattle tending and milking have traditionally been the domain of women (Kaila-Kangas, 2000; Perkiö-Mäkelä, 2000). Hence, limited exposure of men to animals is suggested as an explanation for why the type of farming was not significant in this study. The farm size in terms of cultivated area did not appear to influence the injury rate. Virtanen et al. (2003) observed a non-linear impact of farmland size in Finland; farms with 30 to 49 ha had the highest injury rate. Differences in study design are presumed to explain the difference.

Despite the fact that only one variable was intended for measuring management directly, it must be noted that other variables used in this research also indicate, at least partially, the quality of management. These include the number of machines, musculoskeletal disorders, exhaustion, and health in general. These variables represent outcomes of the selected organization of the operation. For instance, farmers can choose, depending on farm type, from various alternatives for mechanizing operations, which determines the number of machines. Health problems and exhaustion reveal problems in work organization as well, which are naturally related to personal physical and mental characteristics.

The sample of case farms was selected on the basis of reported tractor injuries. The tractor is the basic and most common piece of machinery in farming, regardless of the branch of production. The relative amount of tractor work may differ according to the farm's characteristics, but farms with different branches and sizes were represented in the sample.

The response rate was lower than expected, despite two mailings with a letter of support from the Farmers' Social Insurance Institution enclosed. However, the order of magnitude of the response rate is not uncommon (Brison and Pickett, 1991; Crawford et al., 1998; Lewis et al., 1998). It was possible to compare the size of the farms that answered the inquiry with those that did not answer. In the comparison of arable area, the difference was not significant (about 1 ha). Comparisons with census data showed that some selection bias was likely occurring, but the magnitude of differences was not substantial. Similarity between respondents and non-respondents has been observed in other low response rate studies as well (Lewis et al., 1998). However, this limitation in external validity may affect the extent to which the findings can be generalized. In Finland, $88 \%$ of farmers (principal operators) are male (Yearbook of Farm Statistics, 2001), and as a result, males dominated the study sample.

Self-reporting of injuries is susceptible to recall bias. Owing to the manner of collecting the material, the inquiry or interview reached the target persons about a year after the occurrence of the injury. Slight underreporting may be expected because of imperfect recall (Lewis et al., 1998). The accuracy of the self-reporting is difficult to assess. Nevertheless, the logical relationships noted between factors indicated that the validity of the measurements was good.

Because of the cross-sectional nature of this study, it was not possible to determine the temporal, causal relationships for all the factors. However, several factors related to management and principal operator were resolved.

The results suggest that there are discernible patterns that distinguish high-risk farms from low-risk farms. Specifically, operators reporting high numbers of machines and musculoskeletal disorders appear to have a higher injury rate. Exhaustion among farmers and delays in work can be seen as related to shortcomings of management. Although the findings with the multivariable model were not conclusively supportive for the hypothesis that the quality of farm management has an effect on the safety standards of a farm, results of the crude analysis imply that further research is needed in this area. 


\section{Conclusion}

On the basis of the results, a good working capacity is one precondition for reducing the injury risk on a farm. Good ergonomics in working methods, as well as in machines and equipment, must be further promoted to reduce musculoskeletal disorders. Better business management could result in better quality of operations and in reduction in disturbances and other delays that may be risk factors for injuries.

\section{Acknowledgements}

Appreciation is extended to the Farmers' Social Insurance Institution of Finland, the Academy of Finland, and the University of Helsinki's Department of Agricultural Engineering and Household Technology for sponsoring this project.

\section{References}

Adams, P. R. 1992. Toward a science of accident research. J. Occup. Health and Safety Australia and New Zealand 8(1): 47-51.

Agricultural Census 1990. 1992a. Part 1: Farms. Official Statistics of Finland. Agriculture and Forestry 1. Helsinki, Finland: National Board of Agriculture.

Agricultural Census 1990. 1992b. Part 5: Farmers, Buildings and Machinery. Official Statistics of Finland. Agriculture and Forestry 9. Helsinki, Finland: National Board of Agriculture.

Aschenbrenner, K. M., and B. Biehl. 1994. Improved safety through improved technical measures? Empirical studies regarding risk compensation processes in relation to anti-lock braking systems. In Challenges to Injury Prevention, the Issue of Risk Compensation Behavior, 81-89. R. M. Trimpop and G. J. S Wilde, eds. Groningen, The Netherlands: Styx Publications.

Benson, G. 1999. Risk management planning: What you can do to enhance your chances of success. Management and Marketing Series Fact Sheet 17. Raleigh, N.C.: North Carolina State University. Available at: www.ag-econ.ncsu.edu/faculty/benson/bensonrisk.pdf. Accessed on 11 March 2002.

Boyle, D., S. G. Gerberich, R. W. Gibson, G. Maldonado, R. Ashley Robinson, F. Martin, C. Renier, and H. Amandus. 1997. Injury from dairy cattle activities. Epidemiology 8(1): 37-41.

Brison, R. J., and C. W. L. Pickett. 1991. Nonfatal farm injuries in eastern Ontario: A retrospective survey. Accident Analysis and Prev. 23(6): 585-594.

Browning, S. R., H. Truszczynska, D. Reed, and R. H. McKnight. 1998. Agricultural injuries among older Kentucky farmers: The Farm Family Health and Hazard Surveillance Study. American J. Ind. Med. 33(4): 341-353.

Carstensen, O., J. Lauritsen, and K. Rasmussen. 1995. The West Jutland study on prevention of farm accidents, Phase 1: A study of work specific factors in 257 hospital-treated agricultural injuries. J. Agric. Safety and Health 1(4): 231-239.

Crawford, J. M., J. R. Wilkins 3rd, G. L. Mitchell, M. L. Moeschberger, T. L. Bean, and L. A. Jones. 1998. A cross-sectional case control study of work-related injuries among Ohio farmers. American J. Ind. Med. 34(6): 588-599.

DeRoo, L. A., and R. H. Rautiainen. 2000. A systematic review of farm safety interventions. American J. Prev. Med. 18(4S): 51-62.

Drucker, P. F. 1999. Management Challenges for the 21st Century. Oxford, U.K.: Butterwoth-Heinemann.

Erlich, S. M., T. R. Driscoll, J. E. Harrison, M. S. Frommer, and J. Leigh. 1993. Work-related agricultural fatalities in Australia, 1982-1984. Scandinavian J. Work Environ. Health 19(3): $162-167$.

Eskola, E. 2002. Statistics of Farmers' Social Insurance Institution. Personal communication.

Franklin, R. C., R. J. Mitchell, T. R. Driscoll, and L. J. Fragar. 2001. Agricultural work-related fatalities in Australia, 1989-1992. J. Agric. Safety and Health 7(4): 213-227. 
Geller, J. M., R. L. Ludtke, and T. Stratton. 1990. Nonfatal farm injuries in North Dakota: A sociological analysis. J. Rural Health 6(2): 185-196.

Gerberich, S. G., R. W. Gibson, L. R. French, T.-Y. Lee, P. Carr, L. Kochevar, R. C. Renier, and J. Shutske. 1998. Machinery related injuries: Regional Rural Injury Study - I (RRIS-I). Accident Analysis and Prev. 30(6): 793-804.

Gerberich, S. G., R. W. Gibson, L. R. French, T.-Y. Lee, P. Carr, L. Kochevar, R. C. Renier, and J. Shutske. 2001. Injuries among children and youth in farm households: Regional Rural Injury Study - I. Injury Prevention 7(2): 117-122.

Groeneweg, J. 1992. Controlling the controllable: The management of safety. PhD diss. Leiden, The Netherlands: Leiden University.

Hansson, R., E. Broberg, A. Johansson, U. Jorner, R. Selander, and B. Karlberg-Nilsson. 1989. Undersökning av olycksfallen i jord- och skogsbruket 1987. (Study of accidents in farming and forestry in 1987.) Undersökningsrapport 28. Stockholm, Sweden: Lantbrukshälsan.

Harvey, M. D. 1984. Theories of injury causation. Edmonton, Alberta: Workers' Health, Safety and Compensation, Occupational Health and Safety Division.

Heidt, H., and G. Groh. 1984. Schwerpunkte landwirtschaftlicher Arbeitsunfälle und Möglichkeiten zu ihrer Verhütung. Landtechnik 39(1): 35-40.

Häkkinen, S. 1978. Tapaturmateoriat ja niiden kehittäminen. (Accident theories and their development.) Teollisuustalouden ja työpsykologian laboratoriot. Report 36. Helsinki, Finland: Helsinki University of Technology.

ILO. 2000. Safety and health in agriculture. International Labour Conference, 88th Session, Geneva, June. Report VI (1), Sixth item on the agenda. Geneva, Switzerland: International Labour Office. Available at: www.ilo.org/public/english/standards/relm/ilc/ilc88/rep vi-1.htm. Accessed on 13 Feb. 2002.

Jolly, R. W. 1983. Risk management in agricultural production. American J. Agric. Econ. 65(5): $1107-1113$.

Kaila-Kangas, L., S. Virtanen, and J. Vänskä. 2000. Maatalousyrittäjien työtapaturmat ja koetut työperäiset sairaudet. (Occupational accidents and perceived occupational diseases of farmers.) In Työn vaarat. Koetut työperäiset sairaudet, työtapaturmat ja työväkivaltatapaukset 1999, 79-90. S. Paananen, ed. (Summary and concluding remarks in English.) Labour Market 15. Helsinki, Finland: Statistics Finland.

Laflamme, L. 1990. A better understanding of occupational accident genesis to improve safety in the workplace. J. Occup. Accidents 12(1-3): 155-165.

Lee, T.-Y., S. G. Gerberich, R. W. Gibson, W. P. Carr, J. Shutske, and C. M. Renier. 1996. A population-based study of tractor-related injuries: Regional Rural Injury Study-I (RRIS-I). J. Occup. and Environ. Med. 38(8): 782-793.

Lewis, M. Q., N. L. Sprince, L. F. Burmeister, P. S. Whitten, J. Torner, and C. Zwerling. 1998. Work-related injuries among Iowa farm operators: An analysis of the Iowa Farm Family Health and Hazard Surveillance Project. American J. Ind. Med. 33(5): 510-517.

Maatalouslaskenta 2000. 2001. Maatalouden työvoima. (Labor force in agriculture.) TIKE julkaisu 2. Helsinki, Finland: Maa- ja metsätalousministeriön tietopalvelukeskus.

MacCrawford, J., J. R. Wilkins 3rd, G. L. Mitchell, M. L. Moeschberger, T. L. Bean, and L. A. Jones. 1998. A cross-sectional case control study of work-related injuries among Ohio farmers. American J. Ind. Med. 34(6): 588-599.

Manninen, P. 1996. Risk factors of musculoskeletal disorders and work disability among Finnish farmers. Studies in Social Security and Health 14. Helsinki, Finland: Social Insurance Institution.

McClay, R. E. 1989. Toward a more universal model of loss incident causation, Part I. Professional Safety January: 16-20.

McGwin, G., Jr., R. Enochs, and J. M. Roseman. 2000. Increased risk of agricultural injury among African-American farm workers from Alabama and Mississippi. American J. Epidemiology 152(7): 640-650.

Miller, A., M. Boehlje, and C. Dobbins. 1998. Positioning the farm business. Staff Paper No. 9. West Lafayette, Ind.: Purdue University, Department of Agricultural Economics. Available at: www.agecon.purdue.edu/research/articles/uploaded/positioning.pdf. Accessed on $14 \mathrm{March}$ 2002. 
Murphy, D. J. 1981. Farm safety attitudes and accident involvement. Accident Analysis and Prev. 13(4): 331-337.

Murphy, D. J. 1986. Working unsafely on the farm. Applied Agric. Research 1(1): 2-5.

Nordstrom, D. L., L. Brand, and P. M. Layde, compilers. 1992. Epidemiology of farm-related injuries: Bibliography with abstracts. Purchase Order No. 91-39822. Marshfield, Wisc.: U.S. Department of Health and Human Services, CDC, NIOSH.

Park, H., N. L. Sprince, M. Q. Lewis, L. F. Burmeister, P. S. Whitten, and C. Zwerling. 2001. Risk factors for work-related injury among male farmers in Iowa: A prospective cohort study. J. Occup. Environ. Med. 43(6): 542-547.

Parnell, C. B., B. Shaw, and B. Fritz. 1999. Systems engineering, operations research, and management science. In Plant Production Engineering: CIGR Handbook of Agricultural Engineering, Vol. III, 521-536. B. A. Stout and B. Cheze, eds. St. Joseph, Mich.: ASAE.

Penttinen, J., and P. Valonen. 1995. Tapaturmia ennakoivat tekijät maanviljelijöillä. (Predictive factors for injuries with farmers.) Kuopio, Finland: Kuopion aluetyöterveyslaitos.

Perkiö-Mäkelä, M. 2000. Exercise- and ergonomics-focused promotion of health and work ability in farmers' occupational health services. Kuopio University publications D. Medical Sciences 223. Kuopio, Finland: Kuopion yliopisto.

Pickett, W., L. Hartling, H. Dimich-Ward, J. R. Guernsey, L. Hagel, D. C. Voaklander, and R. J. Brison. 2001. Surveillance of hospitalized farm injuries in Canada. Injury Prevention 7(2): $123-128$.

Rasmussen, J. 1986. Information Processing and Human-Machine Interaction-An Approach to Cognitive Engineering. Amsterdam, The Netherlands: Elsevier Science.

Rasmussen, K., O. Carstensen, and J. M. Lauritsen. 2000. Incidence of unintentional injuries in farming based on one year of weekly registration on Danish farms. American J. Ind. Med. 38(1): 82-89.

Reason, J. 1995. A systems approach to organizational error. Ergonomics 38(8): 1708-1721.

Reason, J. 1997. Managing the Risks of Organizational Accidents. Brookfield, Vt.: Ashgate.

Reis, T. J., and P. D. Elkind. 1997. Influences on farm safety practice in eastern Washington. $J$. Agromed. 4(3/4): 193-205.

Saari, J., and J. Lahtela. 1981. Work conditions and accidents in three industries. Scandinavian J. Work Environ. Health 7(supp. 4): 97-105.

Salminen, S. 1997. Risk taking, attributions and serious occupational accidents. PhD diss. People and Work, Research Report 13. Helsinki, Finland: Finnish Institute of Occupational Health.

Salminen, S., K. L. Saarela, J. Saari, and T. Räsänen. 1991. Human factors in severe occupational accidents due to moving parts of machines. In Contemporary Ergonomics 1991: Ergonomics - Design for Performance: Proc. Ergonomics Society's Annual Conf., 55-60. E. J. Lovesey, ed. London, U.K.: Taylor and Francis.

Schafer, S. R., and J. W. Kotrlik. 1986. Factors affecting farm safety practices. J. Safety Research 17(3): 123-27.

Suutarinen, J. 1992. Tractor accidents and their prevention. Int. J. Ind. Ergonomics 10(4): 321-329.

Suutarinen, J. 1996. Konetöiden turvallisuuden ja tehokkuuden parantaminen. (Developing safety and efficiency of work with machinery.) Vakolan tutkimusselostus 75. Vihti, Finland: Maatalouden tutkimuskeskus.

Suutarinen, J. 1997. Non-fatal tractor accidents and their prevention. J. Agromed. 4(3/4): 313-324.

Thelin, A. 1998. Rollover fatalities-Nordic perspectives. J. Agric. Safety and Health 4(3): 157- 160.

Thu, K., P. Lasley, P. Whitten, M. Lewis, K. Donham, C. Zwerling, and R. Scarth. 1997. Stress as a risk factor for agricultural injuries: Comparative data from the Iowa Farm Family Health and Hazard Survey (1994) and the Iowa Farm and Rural Life Poll (1989). J. Agromed. 4(3/4): $181-191$.

Tupi, K., and I. Vohlonen. 1983. Viljelijöiden työtapaturmat 1979. (Occupational accidents among farmers in 1979.) Helsinki, Finland: Kansaneläkelaitoksen julkaisuja M43. 
Virtanen, S. V., V. Notkola, R. Luukkonen, E. Eskola, and K. Kurppa. 2003. Work injuries among Finnish farmers: A national register linkage study 1996-1997. American J. Ind. Med. 43(3): $314-325$.

Yearbook of Farm Statistics. 2001. Agriculture, Forestry, and Fishery 61. Official Statistics of Finland. Helsinki, Finland: Information Center of the Ministry of Agriculture and Forestry.

Zhao, W., G. H. Hetzel, and F. E. Woeste. 1995. Defining farm safety research priorities by a cost-risk approach. J. Agromed. 2(1): 7-21.

Zwerling, C., N. L. Sprince, C. S. Davis, P. S. Whitten, R. R. Wallace, and S. G. Heeringa. 1998. Occupational injuries among older workers with disabilities: A prospective cohort study of the health and retirement survey, 1992 to 1994. American J. Public Health 88(11): 1691-1695. 